\title{
Why Indigenous Canadians on reserves are reluctant to complain about the police
}

\author{
John Kiedrowski ${ }^{\star}$, Michael Petrunik ${ }^{\dagger}$, and Mark Irving ${ }^{\ddagger}$
}

\begin{abstract}
Recent widespread protests and intensive media coverage of actual and alleged acts of police misconduct against members of vulnerable populations (e.g., Indigenous and racialized persons, mentally ill and/or addicted persons) overrepresented in the criminal justice system have renewed interest internationally in the factors influencing civilian complaints against police. In Canada, a major concern exists regarding how Indigenous persons who feel improperly treated by the police perceive and confront barriers to making formal complaints about such treatment. This study focuses on the Royal Canadian Mounted Police (RCMP), the police agency providing services to the majority of rural and northern reserve communities. Our survey and interviews with influential "community informants" (in this instance community court workers) with intimate knowledge of such local communities, shared culture and language, and vicarious appreciation of the experiences of community members support the view that Indigenous persons do encounter significant barriers to launching formal complaints and are consistent with other research literature. We discuss our findings, raise policy considerations for decision makers such as police leaders and police complaints bodies, and outline implications for future research.
\end{abstract}

Key Words Public complaints; Indigenous policing; Royal Canadian Mounted Police; Police misconduct.

\section{INTRODUCTION}

Indigenous peoples have had a long and difficult relationship with Canada's justice system (Royal Commission on Aboriginal Peoples, 1996; The Truth and Reconciliation Commission of Canada, 2015; and the National Inquiry into Missing and Murdered Indigenous Women and Girls, 2018). In 2017-2018, they accounted for $30 \%$ of all admissions to custody (Malakieh, 2019) and $24 \%$ of the federal corrections population (Public Safety Canada, 2019). In provincial and territorial corrections, Indigenous peoples are overrepresented in arrests and convictions for serious offences (Department of Justice Canada, 2017; Correctional Service of Canada, 2013). In 2018, they were involved in "homicides at a rate nearly eight times greater than non-Indigenous peoples" (Roy \& Marcellus, 2019, p. 14; Beattle et al., 2018).

Despite Indigenous over-representation in involvement with the criminal justice system as victims or offenders, there has not been a corresponding level of formal complaints against the police, the agency that acts as an initial intake into this system. Civilians who make formal complaints can be assumed to do so in their belief that the actions of police were unjustified or unreasonable in their particular case and that they have a right to make this known to public officials (Strudwick, 2003; Smith, 2003; 2009). While the willingness to file complaints in all communities varies in terms of such factors as gender, age, racial/ethnic categorization, mental health/addiction issues, and criminal record, not enough is known about the reasons why few complaints are filed in Indigenous communities despite considerable indications of dissatisfaction with the police (Jones et al., 2014; Kiedrowski et al., 2016; Kiedrowski et al., 2017; Comack, 2012; Public Safety Canada, 2010).

This exploratory study looks at factors influencing Indigenous complaints in Saskatchewan, Canada. We begin by describing the contextual factors that might contribute to complaints and follow with a description of our methodological strategies and data sources. We conclude with a discussion of our findings and their implications for research and policy. Our intent is to shed light on an issue which has proven puzzling: the over-representation of Indigenous peoples in the justice system and their expressions of vocal dissatisfaction with the police while lodging few complaints about their treatment by the police.

\footnotetext{
Correspondence to: John Kiedrowski, Compliance Strategy Group, 74 lona Street, Ottawa, ON K1Y 3L8, Canada. E-mail: jk@compliancestrategygroup.com or John@jkks.ca To cite: Kiedrowski, J., Petrunik, M., \& Irving, M. (2021). Why Indigenous Canadians on reserves are reluctant to complain about the police. Journal of Community Safety and Well-Being, 6131, 148-155. https://doi.org/10.35502/jcswb.201

@ Author(s) 2021. Open Access. This work is distributed under the Creative Commons BY-NC-ND license. For commercial re-use, please contact sales@sgpublishing.ca. SgUBLISHING Published by SG Publishing Inc. CSKA Official publication of the Community Safety Knowledge Alliance.
} 


\section{OVERVIEW OF POLICING AND THE PUBLIC COMPLAINTS SYSTEM}

Policing First Nations communities in Saskatchewan is done mainly through Community Tripartite Agreements (CTA) involving the Government of Canada, the Province of Saskatchewan, and First Nations communities (Kiedrowski et al., 2016). Under the CTA arrangement, First Nations in Saskatchewan receive policing services from a dedicated contingent of RCMP police officers (Kiedrowski et al., 2016). The exception is File Hills First Nations Police Service, a selfadministered stand-alone police agency serving five First Nations communities in the Treaty Four Tribal Territory.

The Civilian Review and Complaints Commission for the RCMP (CRCC) is a federal agency separate from and independent of the RCMP. As set out in the Royal Canadian Mounted Police Act, the CRCC is mandated to accept public complaints about the on-duty conduct of RCMP members, although the Chairperson of the CRCC can also initiate a complaint. Important to note is that the CRCC does not presently collect statistics related to the complainant's race, ethnicity, or Aboriginal identity. Individuals lodging complaints must: (a) have been directly involved in the incident in question; (b) have witnessed the conduct of the RCMP officer(s); or (c) be authorized to act on behalf of the individual directly involved in the incident. A public complaint can be made to either the CRCC, the RCMP, or the "provincial authority responsible for receiving complaints against police in the province in which the subject of the complaint took place" (CRCC, 2018). Typically, the RCMP investigates the complaint in the first instance and reports back to the complainant. A complainant not satisfied with the RCMP's report can ask the CRCC to review the case. In fiscal year 2019-2020, the public lodged a total of 3,641 complaints against the RCMP across Canada; of these, 2,317 were accepted by the CRCC as meeting the legislated criteria for complaints set out in section 45.53 of the Royal Canadian Mounted Police Act (CRCC, 2022).

Some observers have raised legitimate concerns about the composition of police oversight and review agencies (e.g., police complaints bodies and serious incident/special investigations units) across Canada-particularly the lack of racial, ethnic, and gender diversity among investigators. For instance, in 2020, the Canadian Press reported that of the 167 investigators employed in Canada, 111 were former police officers and 118 were men; only 20 investigators identified as non-White. Ghislain Picard, an Indigenous leader, contends that "It's ... the police investigating their own that's totally unacceptable for many people. There is no faith, no trust" (Malone, 2020).

\section{COMPLAINTS ABOUT POLICING}

In the extensive domestic and international literature across many jurisdictions on police complaints and the reasons why individuals do or do not complain (Grossmith et al., 2015; Prenzler et al., 2010; Prenzler, 2004; Rojek et al., 2010; Radford et al., 2005; Smith, 2009, 2003; Terrill \& McCluskey, 2002; MacKinnon, 2019; Waters \& Brown, 2000), the most common criteria used to describe an individual's decision-making when considering filing a complaint are the following:
1. The perceived seriousness of the allegation (Bucke, 1995; Docking \& Bucke, 2006)

2. The degree of self-confidence of would-be complainants (Smith, 2003; Goldsmith, 1991)

3. The degree of confidence in the police and the police complaints system (Donner et al., 2015; Prenzler et al., 2010; Kerstetter, 1996; Landau, 1996)

4. The degree of awareness of the procedures used in registering and investigating police complaints (Schulenburg et al., 2017; Waters \& Brown, 2000; Goldsmith, 1995)

5. The perceived availability of support to complainants throughout the complaints process and afterwards (Ready \& Young, 2015; Scheindlin \& Manning, 2015; Smith, 2009; Strudwick, 2003).

Beyond these general factors, there are specific individual reasons for lodging or not lodging police complaints that need to be considered in the context of particular communities (Rohner, 2020; Freeze, 2019; Annable, 2018). Socially and economically marginalized populations such as Indigenous peoples are likely to be more disadvantaged than other populations for historical reasons such as colonialization (Scott \& Fanon, 2017) and the subsequent loss of culture and language and traditional ways of life (Truth and Reconciliation Commission of Canada, 2015). Indigenous peoples suffer unduly from economic disadvantage, discrimination at a societal level (Rutherford, 2017), addictions and health concerns, high rates of criminal victimization, high suicide rates, and high arrest, conviction, and incarceration rates (Malakieh, 2019). Research on how Indigenous peoples in Canada view police complaint systems is limited. The National Inquiry into Missing and Murdered Indigenous Women and Girls (MMIWG, 2017) found that fear of bullying and retribution when deciding whether to report complaints about the police was not uncommon (MMIWG, 2017). Similarly, Moorcroft (2011) found that women living in the Yukon fear police retaliation if they file a complaint against the police about their behaviour.

Other investigations and commissions have examined the relationships between Indigenous peoples and the police. Sinclair (2018) found that the Indigenous community there does not have confidence in the Thunder Bay Police Service's (TBPS) complaint process. He noted factors such as the perception that police will minimize, dismiss, or fail to investigate with diligence complaints of violence against Indigenous peoples (particularly if intoxicants are known or suspected to be involved) and a fear that formal complaints by Indigenous individuals directed to the TBPS will result in repercussions against the complainant (Sinclair, 2018).

In a similar vein, the Quebec government launched the Public Inquiry Commission on Relations between Indigenous Peoples and Certain Public Services in Québec (PICRIPCPS, 2018). It was established in response to the allegations of discrimination and systemic racism in the police and justice services towards Indigenous persons in northern Quebec. Indigenous witnesses testified to the Commission that they fear and mistrust police officers. The Commission found that it is difficult for an Indigenous person to lodge a complaint about the police directly to members of the police service in a police station where the alleged offending officer might be on the premises. One witness likened the process 
of making a complaint to going into a lion's den (PICRIPCPS, 2018, p. 38).

Tulloch's (2017, p. 236) review of police oversight found that members of Indigenous communities in northern Ontario were often impeded from filing complaints against the police by the remoteness of their communities and by language barriers. McNeilly (2018, p. 24) found that people did not complain about the police for fear of reprisals. Wood (2007, p. 6), as part of his review of the police complaint process in British Columbia, observed that social agencies dedicated to providing services to marginalized groups including Indigenous peoples were often poorly informed about the complaint process. The Union of Ontario Indians (2006) argued that because the members of the policing services lived in the First Nations community, potential complainants hesitated to lodge a complaint against them because of their fear of retribution, either by the police themselves or by other community members concerned about being negatively affected by a complaint.

In 2017, the CRCC for the RCMP (CRCC, 2017) released a report on its investigation into allegations of police misconduct in northern British Columbia. While there were no findings of systemic misconduct, there was evidence of failure to investigate missing persons cases quickly and thoroughly. There are also indications that some policies were inconsistently applied or did not reflect recent developments in common law. The impetus for the CRCC investigation was a series of complaints by individuals documented in inquiries by the British Columbia Civil Liberties Association (2011), the British Columbia Missing Women Commission of Inquiry (2012), and Human Rights Watch (2013). While the CRCC investigated complaints pertaining to the conduct of specific RCMP members, a larger problem identified was the reluctance of First Nations people to lodge complaints against the RCMP in the first place. As the Human Rights Watch (2013, p. 10) report noted, "Fear of retaliation from police runs high in the north, and the apparent lack of genuine accountability for police abuse adds to long-standing tensions between the police and Indigenous communities."

To help support Indigenous peoples living in Saskatchewan in making complaints against the police, the Federation of Sovereign Indigenous Nations (FSIN) created a Special Investigation Unit (SIU) in 2000. The SIU was established after allegations of serious police misconduct including an Indigenous man's complaint that municipal police officers left him on the western edge of the city on a freezing January night and two others died (Saskatoon Star Phoenix, 2017; Wright, 2004). Such acts of police misconduct have shaped many decades of tense relationships between the police and Indigenous peoples in Saskatchewan.

\section{DATA AND ANALYTIC APPROACH}

Our selection of Saskatchewan as a research site was based on the high number of Indigenous peoples residing in remote and rural First Nations communities (Saskatchewan Bureau of Statistics, 2016; Indigenous Services Canada, 2019) and the high number of problematic encounters between Indigenous people and the police expressed in reports of crime, victimization, and public disorder. In addition, there have been many media reports pointing to Saskatchewan's justice system as a "topic of intense scrutiny" (Friesen \& Fine, 2018; Campbell, 2016; Brass, 2004).

A crime-reporting measure used in Canada called the crime severity index (CSI) is instructive when applied to Saskatchewan. In 2018, Saskatchewan led the nation with an overall CSI of 139, almost double the national average of 75 (Moreau, 2019). Furthermore, Saskatchewan's violent crime CSI was the second highest of all the provinces. These crimes are not distributed randomly. Jones et al. (2014) report that several northern First Nations have reported rates of crime that are among the highest in Canada. Rates of crime in rural areas and the provincial north, where the populations of Indigenous peoples are concentrated, are much higher than in the urban centres, and are the highest in the First Nations in Saskatchewan (Perreault, 2019; Malakieh, 2019).

Access to and familiarity with the population under consideration was an important practical consideration for our selection of Saskatchewan as a research site (Reid, 2020; Ruddell \& Kiedrowski, 2020; Kiedrowski \& Petrunik, 2018; Kiedrowski, 2013; Peltier, 2018; Bharadwaj, 2014; Bruhn, 2014; Kowalsky et al., 1996; Macaulay, 1994). The senior researcher was able to use connections made through his work on First Nations governance, policing, and housing (Kovach 2018, 2010; Graveline, 2000) and access to justice and social service workers in Saskatchewan gained during previous research and consultation work. With the help of these connections, consultation on and support and assistance with the study were sought from two First Nations organizations in Saskatchewan.

Given that the members of the research team were outsiders to the communities being studied, such consultation was methodologically essential. As researchers conducting ethnographic community studies have long noted, understanding the views of members of communities vastly different from one's own ty pically requires assistance from community leaders and other "influential informants." These individuals can not only vouch for the legitimacy of the researchers and help them gain access to participants but are also able to provide the benefit of their own direct and vicarious experience of the lives of community members. A much-noted example of this in the research literature is Harvard sociologist William Foot Whyte's use of such "influential informants" in his study of an Italian American community in North Boston. Well-aware of the social distance between himself and the community he was studying and his unfamiliarity with its culture and the social organization of the community, Whyte made use of knowledgeable insiders with direct knowledge and vicarious experience to develop empathic understanding of community members and contextually grounded interpretations of the data he was gathering (Whyte, 1943; Anderson, 2014). The challenges we faced as researchers of events and experiences in communities with which we were socially distant and culturally unfamiliar are akin to what Whyte faced, and we had to find a way to resolve them.

Letters from the two First Nations organizations and researcher were sent to 12 Native court workers who provided services in 13 First Nations communities. All agreed to participate in the study. A 12-question survey instrument was distributed to court workers, who made use of their language and cultural knowledge and direct and vicarious experience of community life in answering questions. One question consisted of eleven statements on filing police complaints. 
Rather than focusing on the degree of agreement/disagreement with the statements by using a scale, respondents were simply asked to either agree, disagree, or express no opinion. Eight open-ended questions asked the participants about their understanding of community members who did not file a formal complaint and their relationship with their family, friends, and community.

In addition to the survey, follow-up telephone interviews of about 50 minutes each conducted with court workers allowed them to elaborate on their initial responses and provide narrative detail (Kilian et al., 2019; Hyett et al., 2018). This combination of survey responses and narrative accounts derived from the interviews allowed us as researchers to gain a deeper interpretive understanding of the reasons provided by court workers as to why many individuals living on reserves are reluctant to file formal complaints against the police.

The individual Indigenous court workers assisting in this study were selected on the basis of their knowledge of local communities, language, and culture, relationships with community members, and knowledge of the criminal justice process gained both formally in their official duties and informally through individual relationships. Note that, to ensure anonymity, neither the names of the communities nor their geographic location were identified.

Court workers provide guidance to Indigenous accused persons with various court processes, including translation and interpretation of information from the court. They may refer accused persons to other agencies and services, if needed, help with liaison, help the clients file a complaint against the police, and follow up on cases (Department of Justice Canada, 2008, 2013; Native Courtworker and Counselling Association of British Columbia, 2014). In some instances, the court workers provide counselling and emotional support of an informal nature to those living in First Nations communities who have had encounters with the police as either alleged offenders or victims (Department of Justice Canada, 2018). The court workers are thus well positioned to observe the relationships of individuals who have problematic encounters with the police that might lead to filing an official complaint.

The approach taken has several limitations. First, there are no formal systems currently in place to identify the number of complaints filed by Indigenous peoples living on reserves in Saskatchewan. Second, we were unable to identify, locate, and interview particular persons who filed complaints. Third, the court workers we used as research informants (although they do have some direct knowledge and vicarious understanding of the communities studied) do not statistically represent a cross section of the members of the communities examined. They can only provide a proxy knowledge. Fourth, no RCMP members whose actions might have been the basis for complaints were interviewed.

\section{RESULTS: DATA ON INDIGENOUS COMPLAINTS}

The CRCC collects data on the number of complaints made against the RCMP but does not currently record, track, or report on socio-demographic characteristics such as age, gender, and Indigenous or non-Indigenous status. We tried to address this gap by using data provided by the CRCC on the number of complaints according to detachment or town/village location directly associated with a specific First Nations community or data that included the specific name of the First Nations community. Based on this source, we were able to identify the number of complaints registered in on-reserve locations versus off-reserve locations in Alberta, Saskatchewan, and Manitoba for the years 2016 to 2018 (see Table I).

Additionally, although the FSIN's SIU has not published formal reports, we obtained some limited complaints-related data from the FSIN. These are presented in Table II, which provides the number of complaints filed through the FSIN's SIU to the CRCC. Between January 1, 2013, and December 31,2017 , the Commission received 21 public complaints from the FSIN about RCMP member conduct related to incidents on a reserve.

TABLE I Number of public complaints made against the RCMP from a reserve for Alberta, Saskatchewan, and Manitoba

\begin{tabular}{cccc}
\hline Year & $\begin{array}{c}\text { On-Reserve } \\
\text { Location }\end{array}$ & $\begin{array}{c}\text { Off-Reserve } \\
\text { Location }\end{array}$ & $\begin{array}{c}\text { Percentage of Total } \\
\text { Complaints Made } \\
\text { from On-Reserve } \\
\text { Location (\%) }\end{array}$ \\
\hline Alberta & 29 & 449 & 6 \\
2016 & 47 & 493 & 9 \\
2017 & 31 & 497 & 6 \\
2018 & & 249 & 16 \\
Saskatchewan & 48 & 218 & 13 \\
2016 & 34 & 179 & 11 \\
2017 & 23 & & 12 \\
2018 & & 133 & 12 \\
Manitoba & 18 & 145 & 9 \\
2016 & 20 & 146 & \\
2017 & 15 & & \\
2018 & 15 & &
\end{tabular}

Source: Civilian Review and Complaints Commission (CRCC), 2019; Alberta Law Enforcement Review Board, 2019; Ministry of Justice and Attorney General (Saskatchewan) Public Complaints Commission, 2017; 2019; Manitoba Office of the Commissioner Law Enforcement Review Agency, 2019.

RCMP = Royal Canadian Mounted Police.

TABLE II Number of complaints from FSIN to CRCC, 2013-2017

\begin{tabular}{cc}
\hline Year & Complaints Against the RCMP on Reserve \\
\hline 2013 & 4 \\
2014 & 4 \\
2015 & 3 \\
2016 & 8 \\
2017 & 2 \\
\hline Source: Civilian Review and Complaints Commission (CRCC), 2019. \\
FSIN = Federation of Sovereign Indigenous Nations; RCMP = Royal \\
Canadian Mounted Police.
\end{tabular}




\section{FINDINGS}

Table III provides the responses of court workers in our study to a series of 11 statements on why Indigenous community members are reluctant to file a formal complaint against the RCMP. Five respondents indicated community members feared something negative would happen if a complaint was made against the RCMP. Five, five, nine, and four respondents expressed little confidence that complaints filed would be taken seriously by the RCMP (statements b, c, d, and h, respectively). In terms of the actual process for filing complaints, respondents noted a number of problems with this process. Five, six, four, and six respondents, respectively stated the process is too complicated (statement e), the process takes too long to investigate (statement $i$ ), the persons filing the complaints are not properly informed about the progress of their complaint (statement $\mathrm{f}$ ), and the complaints made by the individual may not be considered valid (statement $g$ ). In response to the statement "The agency responsible to investigate the complaint against the RCMP will provide an objective assessment of the file," six respondents had no opinion and five agreed with the statement. These responses are complemented by those made to statement k: "The members of your community are unaware of the CCRC for the RCMP." Here, 10 persons agreed with this statement on the basis that only a very few people know about the process for filing a complaint against the RCMP.

One of the persons who provided an "agree" response stated that, although "some people are aware, information is not posted publicly, making access to it difficult. Most people want someone else to file the complaint on their behalf." Lastly, four of the respondents who provided an "agree" response stated that the information on the complaints process (i.e., posters, applications) needs to be in the Dene or Cree languages.

To further understand the impact or influence of family members, friends, and the community on whether an individual will file a complaint against the police, the respondents were asked to provide their views on specific questions. With respect to the question, "Do you believe there are pressures from family members placed on a community member to not file a complaint against the RCMP," eight of the respondents stated family does influence or put pressure on individuals to not file a complaint. One comment that stood out was, "family members will encourage them to 'let sleeping dogs lie' rather than complain."

Similarly, the respondents were asked whether they "believe there are pressures from friends (e.g., boyfriend/ girlfriend, friends from school) on a community member to not file against the RCMP." In this case, 10 of the respondents were of the view that there are pressures from friends on community members to not file a complaint. The following are some of the reasons included: it is a waste of time; don't want to be viewed as a troublemaker or a bad person; living in a remote community where everyone knows everyone else's business leads to rumours, conspiracy theories, gossiping, and nothing being kept confidential.

When asked whether they "believe there are any consequences (negative or positive) from the community against a community member who does not file a complaint," seven respondents expressed their belief that the community at large does not play a role in whether a person will file a complaint.

Finally, the respondents were asked to provide further comments regarding the filing of complaints. Some stated that few of those working in the area of justice and court workers know about the CRCC and the public complaints process while others commented that there is a lack of information on how to file a complaint.

\section{CONCLUSION}

This exploratory study asks why Indigenous peoples residing on reserve seldom launch formal complaints about the

TABLE III Respondents' views on statements on filing police complaints and processes

\begin{tabular}{|c|c|c|c|}
\hline Statements & Agree & Disagree & $\begin{array}{l}\text { No } \\
\text { Opinion }\end{array}$ \\
\hline $\begin{array}{l}\text { The community member fears something negative would happen if a complaint is made against } \\
\text { the RCMP. }\end{array}$ & 5 & 5 & 2 \\
\hline The RCMP investigate the RCMP therefore nothing will happen. & 5 & 6 & 1 \\
\hline The community member's complaint against the RCMP will be ignored. & 5 & 6 & 1 \\
\hline The community member's complaint against the RCMP will not be taken seriously. & 9 & 2 & 1 \\
\hline The process to file a complaint against the RCMP is too complicated. & 5 & 4 & 3 \\
\hline $\begin{array}{l}\text { The community member who files a complaint against the RCMP is not properly informed about } \\
\text { the progress of their complaint. }\end{array}$ & 4 & 3 & 5 \\
\hline The community member's complaint against the RCMP may not be viewed as valid. & 6 & 3 & 3 \\
\hline The process to file a complaint against the RCMP is a waste of time as nothing will happen. & 4 & 6 & 2 \\
\hline The community member's complaint against the RCMP takes too long to investigate. & 6 & 1 & 5 \\
\hline $\begin{array}{l}\text { The agency responsible to investigate the complaint against the RCMP will provide an objective } \\
\text { assessment of the file. }\end{array}$ & 5 & 1 & 6 \\
\hline $\begin{array}{l}\text { The members of your community are unaware of the Civilian Review and Complaints Commission } \\
\text { for the RCMP. }\end{array}$ & 10 & & 2 \\
\hline
\end{tabular}

RCMP = Royal Canadian Mounted Police 
perceived or actual misbehaviour of and abuse of authority by police officers. The research focused on First Nations communities in the province of Saskatchewan, which has the highest proportion of Indigenous peoples in its population as well as the highest rates of the volume and seriousness of overall crime in Canada.

Data from the survey instrument and interviews show that respondents considered the complaint process itself to be unclear or intimidating for community members. Respondents also noted that community members expressed a lack of self-confidence, sense of self-worth, and resources (education, competency in communication) to file a complaint against the police, had concerns about bias, and feared the potential consequences (for example, retribution) that filing complaints might have for themselves, family, and friends.

These findings are consistent with those reported in research by Smith (2003), Goldsmith (1991), Phau \& Baird (2008), Volkov et al., (2002), and Wagner \& Decker (1993) and, together with Wagner (1980), provide a roadmap for increasing understanding of the complaint process and removing potential barriers to Indigenous peoples making complaints. They come at a time when the federal government and the RCMP are being criticized by government opposition parties and others face increased scrutiny to address systemic racism. In the words of one criminologist: "the RCMP investigating the RCMP is totally unacceptable. Nobody in their right mind today accepts the idea that a police agency is capable, independent and unbiased, yet they are the ones that do the investigations" (Ballingall, 2020).

With regard to implications for future research and policy, more extensive research is required to understand the reasons why complaints are not filed by individuals living on and off reserve, and what processes are required to assist them in submitting complaints to the appropriate police complaints bodies. A challenge in comparing complaints on and off reserve is that many members of Indigenous communities, especially those living in remote areas, do not have home addresses and must rely on a Post Office (PO) Box, General Delivery, or Rural Route designation for their incoming mail. Obtaining a better understanding and appreciation of wouldbe and actual Indigenous complainants' confidence in and satisfaction with police complaints systems will better inform the development and implementation of culturally sensitive and appropriate complaints mechanisms and processes in addition to police complaint bodies' public education, awareness, and outreach efforts. Also, in order to obtain a more accurate and complete picture of who is actually lodging complaints against the police, public complaints bodies need to start systematically gathering and analyzing data and information related to complainants. At the same time, these complaint bodies need to consider and acknowledge the "dark figure" of complaints - that is, those who would like to lodge a complaint against the police but for various reasons fear doing so or cannot do so. Public complaint bodies should then carefully (re)examine their policies, procedures, and processes to see whether there are disparities and barriers to lodging a complaint that can be minimized or removed altogether.

\section{CONFLICT OF INTEREST DISCLOSURES}

The authors have no conflicts of interests to declare. Mr. Irving was a Senior Research Advisor with the CRCC from October 2010 to March 2021.

\section{AUTHOR AFFILIATIONS}

*President, Compliance Strategy Group, Ottawa, ON, Canada; ${ }^{\dagger}$ Retired Professor, Criminology Department, University of Ottawa, Ottawa, ON, Canada; ${ }^{\ddagger}$ Centre for Crime, Justice and Policing, University of Birmingham, Birmingham, UK.

\section{REFERENCES}

Alberta Law Enforcement Review Board. (2019). 2018 Annual report. Edmonton AB. Retrieved from https://open.alberta.ca/dataset/ 270e9a71-b6af-4le5-9adc-8360ea28969b/resource/a682abf63f9d-4039-839e-28cf2073edbe/download/lerb-2018-annualreport-web.pdf.

Anderson, O. (2014). William Foote Whyte, street corner society and social organization. Journal of the History of the Behavioral Sciences, 50(1), 79-103

Annable, Kristin. (2018, April 6). Most people who died in police encounters in Manitoba were Indigenous, CBC investigation finds. https:// www.cbc.ca/news/canada/manitoba/deadly-force-manitobaindigenous- 1.4607383

Ballingall, A. (2020, June 17). Who investigates complaints about the RCMP? In "99.9\%" of cases, it's the RCMP. The Star. https://www. thestar.com/politics/federal/2020/06/17/who-investigatescomplaints-about-the-rcmp-in-999-of-cases-its-the-rcmp.html

Beattle, S., David, J. D., \& Roy, J. (2018). Homicide in Canada, 2017. Catalogue No. 85-002-X.

Bharadwaj, L. (2014). A framework for building research partnerships with First Nations communities. Environmental health insights, 8 , EHI-S10869

Brass, M. (2004). Starlight Tours. CBC Online. http://www.cbc.ca/ news2/background/aboriginals/starlighttours.html

British Columbia Civil Liberties Association. (2011). Small town justice: A report on the RCMP in Northern and Rural British Columbia. Civil Liberties Association.

British Columbia, Missing Women Commission of Inquiry (2012). Forsaken - Report of the Missing Women Commission of Inquiry: Executive Summary, Commissioner: The Honourable Wally T. Oppal. Shared Services British Columbia.

Bruhn, J. (2014). Identifying useful approaches to the governance of Indigenous data. The International Indigenous Policy Journal, 5(2), 5.

Bucke, T. (1995). Policing and the public: Findings from the 1994 British crime survey. Home Office Research and Statistics Department Research Findings No. 28. HMSO.

Campbell, M. (2016). New light on Saskatoon's "Starlight Tours." An attempt to erase reference to the deadly practice from the police force's Wikipedia page stirs up dark memories, and new questions. Maclean's. http://www.macleans.ca/news/canada/new-light-onsaskatoons-starlight-tours/

Civilian Review and Complaints Commission for the RCMP. (2017). Chairperson-initiated complaint and public interest investigation regarding policing in northern British Columbia: Chairpersons' final report after Commissioner's response. Civilian Review and Complaints Commission for the RCMP.

Civilian Review and Complaints Commission for the RCMP. (2018). Complaint and review process flowchart. https://www.crcc-ccetp. gc.ca/en/complaint-and-review-process-flowchart

Civilian Review and Complaints Commission for the RCMP. (2019). Provincial reports - April 1, 2018 to March 31, 2019. Unpublished data. CRCC.

Civilian Review and Complaints Commission for the RCMP. (2022). Annual Report: 2019-2020. CRCC.

Comack, E. (2012). Racialized policing. Aboriginal people's encounters with the police. Halifax, NS. Fernwood Publishing. 
Correctional Service of Canada. (2013). Demographic overview of Aboriginal peoples in Canada and Aboriginal offenders in federal corrections. http://www.csc-scc.gc.ca/aboriginal/002003-1008eng.shtml

Department of Justice Canada. (2008). Aboriginal Courtwork program. Summative evaluation. Final report. Department of Justice Canada.

Department of Justice Canada. (2013). Aboriginal Courtwork program evaluation. Final report (March). Evaluation Division Office of Strategic Planning and Performance Management. Department of Justice.

Department of Justice Canada. (2017). Indigenous overrepresentation in the criminal justice system. Just Facts https://www.justice.gc.ca/eng/ rp-pr/ir/if-pf/2017/docs/jan02.pdf.

Department of Justice Canada. (2018). Evaluation of the Indigenous Courtwork program. Final Report. Evaluation Division Corporate Services Branch, Department of Justice.

Docking, M., \& Bucke, T. (2006). Confidence in the police complaints system. IPCC Research and Statistics Series Paper 2. Independent Police Complaints Commission.

Donner, C., Maskaly, J., Fridell, L., \& Jennings, W. G. (2015). Policing and procedural justice: A state-of-the-art review. Policing: An International Journal of Police Strategies \& Management, 38(1), 153-172.

Freeze, C. (2019, November 17). More than one-third of people shot to death over a decade by RCMP officers were Indigenous. https:// www.theglobeandmail.com/canada/article-more-than-one-third-of people-shot-to-death-over-a-decade-by-rcmp

Friesen, J., \& Fine, S. (2018, February 16). Stanley murder acquittal inflames Indigenous people's loss of faith in Canada's justice system. https:// www.theglobeandmail.com/news/national/stanley-murder-acquittaljust-the-latest-case-to-test-indigenous-peoples-faith-in-canadas-courts/ article38013859/

Goldsmith, A. (1991). Complaints against the police: The trend to external review. Clarendon Press.

Goldsmith, A. (1995). Necessary but not sufficient: The role of public complaints procedures in police accountability. In P. Stenning (Ed.), Accountability for criminal justice. University of Toronto.

Graveline, F. J. (2000). Circle as methodology: Enacting an aboriginal paradigm. International Journal of Qualitative Studies in Education, $13,361-370$.

Grossmith, L., Owens, C., Finn, W., Mann, D., Davies, T. \& Baika, L. (2015). Police, camera, evidence: London's cluster randomised controlled trial of Body Worn Video. College of Policing.

Human Rights Watch. (2013). Those who take us away: Abusive policing and failures in protection of Indigenous women and girls in Northern British Columbia, Canada. Human Rights Watch.

Hyett, S., Marjerrison, S., \& Gabel, C. (2018). Improving health research among Indigenous peoples in Canada. Canadian Medial Association Journal, 190, E616-E621. https://doi.org/10.1503/cmaj.171538

Indigenous Services Canada. (2019). National overview of the community well-being index, 1981 to 2016. https://www.sac-isc.gc.ca/DAM/ DAM-ISC-SAC/DAM-STSCRD/STAGING/texte-text/nat-overviewcommunity-well-being-index-1981-2016_1578933849349_eng.pdf

Jones, N. A., Ruddell, R., Nestor, R., Quinn, K., \& Phillips, B. (2014). First Nations policing-A review of the literature. Department of Justice Studies, University of Regina.

Kerstetter, W. (1996). Towards justice for all: Procedural justice and the review of citizen complaints. In W. Geller \& H. Toch (Eds.), Police violence: Understanding and controlling police abuse of force (pp. 234-246). Yale University Press.

Kiedrowski, J. (2013). Trends in Indigenous policing models: An international comparison. Ottawa ON: Public Safety Canada.

Kiedrowski, J. S., Jones, N. A., \& Ruddell, R. (2017). "Set up to fail?" An analysis of self-administered indigenous police services in Canada. Police Practice and Research, 18(6), 1-15.
Kiedrowski, J., \& Petrunik, M. (2018). An exploratory analysis of Aboriginal complaints against the Royal Canadian Mounted Police in Saskatchewan. Compliance Strategy Group.

Kiedrowski, J. S., Petrunik, M., \& Ruddell, R. (2016). Illustrative case studies of First Nations policing program models. Public Safety Canada.

Kilian, A., Fellows, T. K., Giroux, R., Pennington, J., Kuper, A., Whitehead, C. R., \& Richardson, L. (2019). Exploring the approaches of nonIndigenous researchers to Indigenous research: A qualitative study. Canadian Medical Association Journal Open, 7(3), E504-E509.

Kovach, M. (2010). Conversational method in Indigenous research. First Peoples Child \& Family Review, 5, 40-48.

Kovach, M. (2018). Doing Indigenous methodologies-A letter to a research class. In N. K. Denzin \& Y. S. Lincoln (Eds.), The Sage Handbook of Qualitative Research, 5th ed. (pp. 214-235). Sage.

Kowalsky, L. O., Thurston, W. E., Verhoef, M. J., \& Rutherford, G. (1996). Guidelines for entry into an Aboriginal community. Canadian Journal of Native Studies, 1612), 267-282.

Landau, T. (1996). When police investigate police: A view from complainants. Canadian Journal of Criminology, 38(3), 291-315.

Macaulay, A. C. (1994). Ethics of research in native communities. Canadian Family Physician, 40, 1888-1897.

MacKinnon, C. (2019, January 15). Quebec's police watchdog flooded with complaints from Indigenous people about police misconduct. CBC News. https://www.cbc.ca/news/canada/montreal/beiindigenous-complaints- 1.4978180

Malone, K. G. (2020, June 19). "Totally unacceptable:" Most independent investigators white, former officers. The Canadian Press. https:// www.ctvnews.ca/canada/totally-unacceptable-most-independentinvestigators-white-former-officers-1.4991079

Malakieh, J. (2019). Adult and youth correctional statistics in Canada, 2017/2018. Juristat, Catalogue no. 85-002-X.

Manitoba Office of the Commissioner Law Enforcement Review Agency. (2019). Annual report 2018. Winnipeg, MB: Manitoba Justice.

McNeilly, G. (2018). Broken Trust: Indigenous people and the Thunder Bay Police Service. Office of the Independent Police Review Director.

Ministry of Justice and Attorney General (Saskatchewan) Public Complaints Commission. (2019). Annual report for 2018-2019. Regina, SK: Ministry of Justice and Attorney General.

Ministry of Justice and Attorney General (Saskatchewan) Public Complaints Commission. (2017). Annual report for 2017-2018. Regina, SK: Ministry of Justice and Attorney General.

Moreau, G. (2019, July 22). Police-reported crime statistics in Canada, 2018, Juristat. Catalogue no. 85-002-X.

Moorcroft, L. (2011). If my life depended on it: Yukon women and the RCMP. Advisory Committee member representing Yukon women's groups.

National Inquiry into Missing and Murdered Indigenous Women and Girls. (2017). Our women and girls are scared: Interim report. Privy Council Office.

National Inquiry into Missing and Murdered Indigenous Women and Girls. (2018). Interim report: Our women and girls are sacred. National Inquiry into Missing and Murdered Indigenous Women and Girls.

Native Courtworker and Counselling Association of British Columbia. (2014). Community engagement. http://nccabc.ca/family-and-youthservices/community-involvement/

Peltier, C. (2018). An application of two-eyed seeing: Indigenous research methods with participatory action research. International Journal of Qualitative Methods, 17111, 1609406918812346.

Perreault, S. (2019, May 7). Police-reported crime in rural and urban areas in the Canadian provinces, 2017. Juristat. Catalogue no. 85-002-X.

Phau, I., \& Baird, M. (2008). Complainers versus non-complainers retaliatory responses towards service dissatisfactions. Marketing Intelligence \& Planning, 26(6), 587-604. 
Prenzler, T. (2004). Stakeholder perspectives on police complaints and discipline: Towards a civilian control model. Australian and New Zealand Journal of Criminology, 37(1), 85-113.

Prenzler, T. J., Allard, T. J., Curry, S., \& Macintyre, S. (2010). Complaints against police: The complainants' experience. The Journal of Criminal Justice Research, 1, 1-18.

Public Inquiry Commission on relations between Indigenous Peoples and certain public services in Québec. (2018, December 14). Listening, reconciliation and progress. Joint Final Presentation Grand Council of the Crees (Eeyou Istchee). Cree Nation Government Cree Board of Health and Social Services of James Bay. https://www.cerp. gouv.qc.ca/fileadmin/Fichiers_clients/Documents_deposes_a_la_ Commission/P-1357.pdf

Public Safety Canada. (2010). 2009-2010 Evaluation of the First Nations policing program. Public Safety Canada.

Public Safety Canada. (2019). Corrections and conditional statistics overview: 2018 annual report. Public Safety Canada.

Radford, K., Hamilton, J., \& Jarman, N. (2005). "It's their word against mine": Young people's attitudes to the police complaints procedure in Northern Ireland. Children \& Society, 19(5), 360-370.

Ready, J. T., \& Young, J. T. (2015). The impact of on-officer video cameras on police-citizen contacts: Findings from a controlled experiment in Mesa, AZ. Journal of Experimental Criminology, 11, $445-458$.

Reid, B. (2020). Positionality and research: "Two-Eyed Seeing" with a rural Ktaqmkuk Mi'kmaw community. International Journal of Qualitative Methods, 19, 1609406920910841.

Rohner, Thomas. (2020, June 15). "Completely Toothless": Experts say Nunavut's police oversight less accountable than others. https:// www.cbc.ca/news/canada/north/nunavut-rcmp-police-oversight1.5612591

Rojek, J., Decker, S., \&Wagner, A. (2010). Addressing police misconduct: The role of citizen complaints. In R. Dunham \& G. Alpert (Eds.), Critical issues in policing: Contemporary readings (pp. 292-312). Waveland Press.

Roy, J., \& Marcellus, S. (2019). Homicide in Canada 2018. Juristat Catalogue no. 85-002-X

Royal Canadian Mounted Police Act RSC 1985, c R-10.

Royal Commission on Aboriginal Peoples. (1996). Report of the Royal Commission on Aboriginal people. https://www.bac-lac.gc.ca/ eng/discover/aboriginal-heritage/royal-commission-aboriginalpeoples/Pages/final-report.aspx

Ruddell, R., \& Kiedrowski, J. (2020). Reforming Indigenous policing: Understanding the context for change. Journal of Community Safety and Well-Being, 5(4), 144-155. https://doi.org/10.35502/ jcswb. 168

Rutherford, S. (2017). "We have bigotry all right-but no Alabamas": Racism and aboriginal protest in Canada during the 1960s. American Indian Quarterly, 47(2), 158-179.

Saskatchewan Bureau of Statistics. (2016). Saskatchewan Aboriginal Peoples 2016 Census. Regina, SK. http://www.stats.gov.sk.ca/stats/ pop/2016\%20Aboriginal\%20People\%20pdf

Saskatchewan Bureau of Statistics. (2016). Saskatchewan population report. Regina, SK: Ministry of Finance.

Saskatoon Star Phoenix. (2017, January 28). The FSIN's special investigation unit is facing an uncertain future after a reduction in funding from the province. http://thestarphoenix.com/storyline/the-federation-ofsovereign-indigenous-nations-is-hopeful-its-investigation-unit-fundingis-secure

Statistics Canada. (2018). Alberta (on reserve) [Historic treaty area], Alberta (table). Aboriginal population profile. 2016 Census. Statistics
Canada Catalogue no. 98-510-X2016001. Ottawa. Released July 18,2018

Statistics Canada. (2018). Manitoba lon reserve) [Historic treaty area], Manitoba (table). Aboriginal population profile. 2016 Census. Statistics Canada Catalogue no. 98-510-X2016001. Ottawa. Released July 18, 2018

Statistics Canada. (2018). Saskatchewan (on reserve) [Historic treaty area], Saskatchewan (table). Aboriginal population profile. 2016 Census. Statistics Canada Catalogue no. 98-510-X2016001.

Scheindlin, S. A., \& Manning, P. K. (2015). Will the widespread use of police body cameras improve police accountability? Americas Quarterly, 9(2), 24-27.

Schulenberg, J. L., Chenier, A., Buffone, S., \& Wojciechowski, C. (2017). An application of procedural justice to stakeholder perspectives: Examining police legitimacy and public trust in police complaints systems. Policing and Society, 2717), 779-796

Scott, D. C., \& Fanon, F. (2017). Breakage: colonization, violence, and the possibility (still) of a self-determined destiny. In J. Dhillon (Ed.), Prairie Rising: Indigenous Youth, Decolonization, and the Politics of Intervention, (pp. 47-78). University of Toronto Press.

Sinclair, M. (2018). Thunder Bay police service board investigation. Final report. https://slasto-tsapno.gov.on.ca/ocpc-ccop/wp-content/ uploads/sites/5/2018/12/TBPSB_Investigation_Final_Report_-EN-FINAL-1.pdf

Smith, G. (2009). Why don't more people complain against the police? European Journal of Criminology, 6(3), 249-266.

Smith, G. (2003). Actions for damages against the police and the attitudes of claimants. Policing and Society, 13, 413-22.

Statistics Canada. (2018). First Nations People, Métis and Inuit in Canada: Diverse and growing populations. Catalogue 89-659-X.

Strudwick, K. (2003). Is independence the only answer to complainants' satisfaction of the police complaints process? A perspective from the United Kingdom, Police Practice and Research, 4(1), 35-46.

Terrill, W., \& McCluskey, J. (2002). Citizen complaints and problem officers: Examining officer behaviour. Journal of Criminal Justice, $30(2), 143-155$.

Truth and Reconciliation Commission of Canada. (2015). Final report of the truth and reconciliation commission of Canada, Volume One: Summary. James Lorimer and Company.

Tulloch, M. H. (2017). Report of the independent police oversight review. Queen's Printer for Ontario.

Union of Ontario Indians. (2006). Ipperwash inquiry part II community consultations. Final Report.

Volkov, M., Harker, D., \& Harker, M. (2002). Complaint behaviour: A study of the differences between complainants about advertising in Australia and the population at large. Journal of Consumer Marketing, 19(4), 319-332.

Wagner, A. E. (1980). Citizen complaints against the police: The complainant. Journal of Police Science \& Administration 8, 247-252.

Wagner, A. E., \& Decker, S. H. (1993). Evaluating citizen complaints against the police. In R. G. Dunham \& G. P. Alpert (Eds.), Critical Issues in Policing (pp. 275-291). Prospect Heights, IL: Waveland Press.

Waters, I., \& Brown, K. (2000). Police complaints and the complainant's experience. The British Journal of Criminology, 40(4), 617-638.

Whyte, W. F. (1943). Street corner society: The social structure of an Italian slum. University of Chicago Press.

Wright, D. H. (2004). Report of the commission of inquiry into matters relating to the death of Neil Stonechild. Government of Saskatchewan.

Wood, J. (2007). Report on the review of the police complaint process in British Columbia. Blakes. 